\title{
Viability of lateritic soil as alkaline activated precursor
}

\author{
Luiz Pereira-de-Oliveira ${ }^{1,}$ Lucio Macedo ${ }^{2}$, José $\mathrm{Neto}^{2}$, Dellane Santos ${ }^{2}$ and Hugo Silva ${ }^{2}$ \\ ${ }^{1}$ University Ceuma, São Luis, Brazil/Centre of Materials and Building Technologies, Portugal \\ ${ }^{2}$ University Ceuma, São Luis, Brazil
}

\begin{abstract}
This study investigates the disposal of lateritic soil available in the state of Maranhao, Brazil, to be used as a natural precursor of alkaline activated material. Lateritic soils are formed in the tropics through weathering processes that favour the formation of iron, aluminium and may contain a large amount of quartz and kaolinite. The quality of laterite for this application may vary significantly depending on both geographic location and depth of a quarry. The identification of quarry locals was carried out in this work, together with a disposal volume estimation considering economic issues about exploration techniques. A comparison of the chemical composition of the lateritic soil of the state of Maranhao with those related in the literature is used to outline the feasibility of using this natural material as precursor of alkaline activated cements. It is concluded that the lateritic soil availability, as well as their characteristics, can enable the development of alkaline activated materials as a future local building material and environmentally friendly.
\end{abstract}

\section{Introduction}

Lateritic clays characterized by a pronounced reddish or yellow colour and are mostly found in leached soils of humid tropical and sub-tropical regions [1,2]. The lateritic soil has concentrated oxides of iron and/or aluminium, with kaolinite as the predominant clay mineral [2,3]. The lateritic material, as stone and aggregates, have been traditionally used as cheap common building materials in developing countries [4-6]

Various stabilization techniques nowadays often improve the structural performance of laterites such as mechanical and chemical stabilization. Lemougna et al. [7], report one kind of mechanical stabilization involves simple compression of laterite soil, eventually mixed with cement forming the so-called compressed earth blocks. The most common chemical stabilization is based on pozzolanic reactions through the addition of lime or anhydrous calcium silicates. Lecomte-Nana et al. [8] recently suggested the use of a two-step reaction involving acid dissolution of iron minerals in laterite followed by lime treatment. According to the authors, the binding action of iron through chemical bridging of the clay particles contributed to the pozzolanic binding action between lime and the clay minerals.

A less studied, but promising, technique is the alkaline activation of the aluminosilicates present in laterite $[9,10]$. This process can basically be described as a transformation of a solid aluminosilicate precursor into an alkali aluminosilicate inorganic polymer [11, 12]. The resulting material is an amorphous structure consisting of $\left[\mathrm{SiO}_{4}\right] 4$ - and $\left[\mathrm{AlO}_{4}\right] 5$ - tetrahedral sharing all the corners with each other. The exchange of silicon for aluminium results in a net negative charge which is compensated by alkali cations [11]. This reaction may take place in highly concentrated alkaline solutions at mild temperatures. The alkaline activated materials are not only a more environmental friendly alternative to traditional Portland cement [13], but can also be produced using industrial wastes which otherwise are deposited in landfills [12].

Thus, the present study has been performed with an aim to explore the viability to use the lateritic soil from São Luis do Maranhão, Brazil as an alkaline activated precursor. In this study, emphasis is made on laterite soil occurrence and quarries and their chemical composition to find optimal formulation and to reach a high quality and reproducible material.

\section{Lateritic soils}

Lateritic soils are widely distributed throughout the world in the regions with high rainfall, but especially in the inter-tropical regions of Africa, Australia, India, South-East Asia and South America, where they generally occur just below the surface of grasslands or forest clearings [14, 15]. Lateritic soils are formed through weathering processes in the tropics that favour the formation of iron, aluminium, manganese and titanium oxides. These processes break down silicate minerals into clay minerals such as kaolinite and illite.

Fig. 1 shows the main regions where the lateritic soil is found [16].

* Corresponding author: luizpeoli@gmail.com 


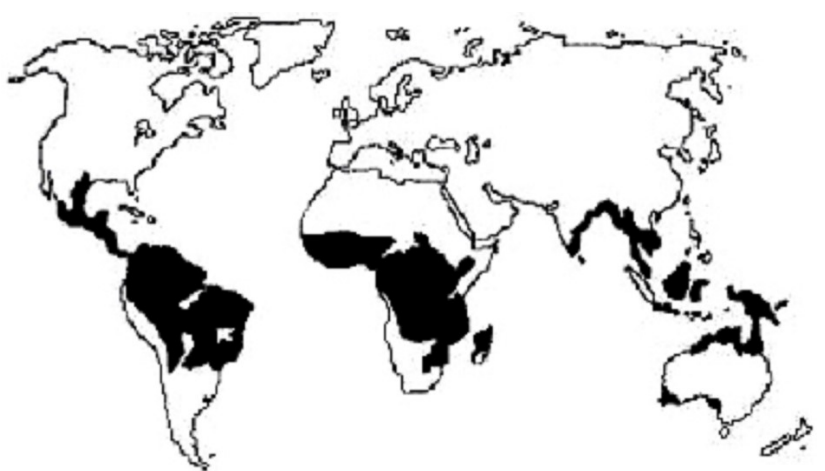

LATERITIC SOLLS

Fig 1. Distribution of lateritic soils in the World [16].

The alteration of various original rocks such as olivine, magnetite, ilmenite, feldspar, quartz and clay minerals start the laterite genesis followed by capillary solution and deposition of inorganic matter. This so called metasomatic alteration forms a new mineral, of partly or completely different chemical composition. In fact, the soil composition is influenced by actions of temperature change and rain draining water [17, 18]. In lateritic soils profiles, the upper levels are constituted by an accumulation of sexquioxides (iron, aluminium) and lower levels by kaolinization. When exposed to the atmosphere the laterite can harden due to a dehydration process. This hardening process is caused by the precipitation, concentration and crystallization of $\mathrm{Fe}_{2} \mathrm{O}_{3}$ and $\mathrm{Al}_{2} \mathrm{O}_{3}$. The iron migration towards the soil profile is enhanced by water lixiviation, which explains the iron concretions observed in depth [17].

Previous works on lateritic soils of the tropical and subtropical countries used in construction showed that some of their physical and mechanical properties can be improved by the process of chemical stabilization [1921]. However, up to date, the improvements made on these soils for construction purposes are limited to the use of ordinary Portland cement (OPC) as the stabilizer.

Lateritic soils are commonly found in Maranhão State, on nearly $35 \%$ of the territory, in area of $116.541,5$ $\mathrm{km}^{2}$, located inside the red triangle in Fig. 3 [22]. In the south-eastern of Maranhão state (transition from superhumid Amazonian to semi-arid Northeast), torrential rains concentrated in the humid period have provoked strong stripping of the mantle, even exposing laterites to the surface, associated with residual soils poorly developed [23].

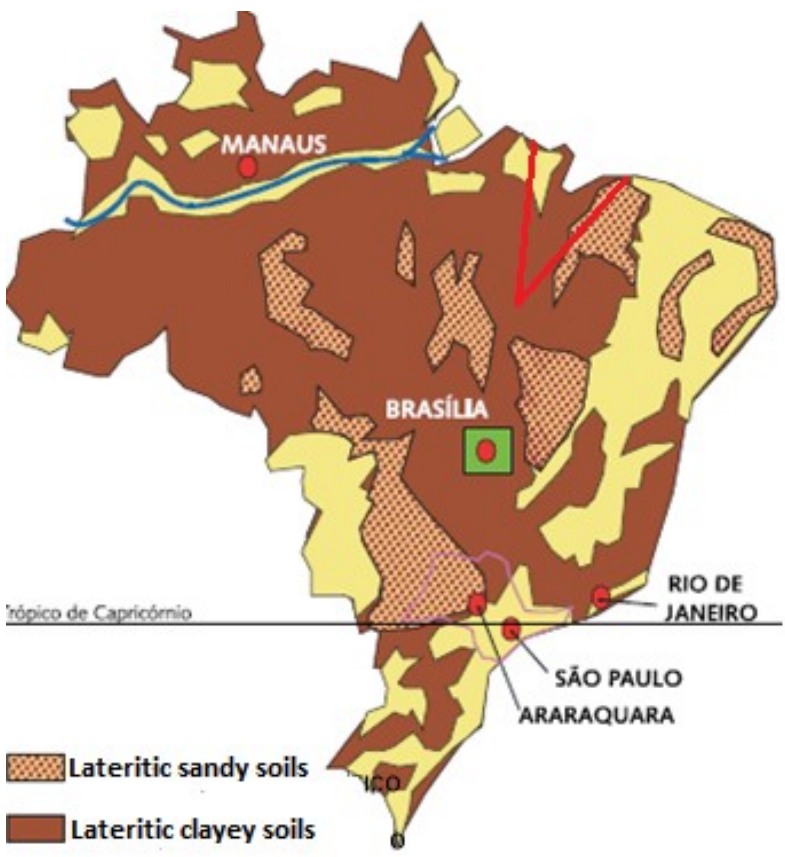

Fig. 2. Occurrence of lateritic soils in Brazil [22]

\subsection{Lateritic soils as precursor of alkaline activated binder}

Even though the lateritic soil alkaline activation process was described to be energy efficient and environmentally friendly, very limited studies were carried out and reported in tropical countries [24, 25, 26], and especially in Brazil where the housing deficit and need for affordable building materials remain a great concern.

Table 1 shows the composition of laterites found in Cameroon reported in some recent works [27-29], generally these laterites have kaolinite, halloysite and illite as the main clay minerals, associated with quartz, iron oxides and sometimes titanium oxides [19,20,26]. The reactivity of the kaolinite mineral in alkaline medium producing zeolitic like materials is well known $[25,30,31]$. However, the presence of other associated minerals in a lateritic soil containing kaolinite could greatly affect the reactivity of this mineral.

Table 1. Chemical composition of the laterites

\begin{tabular}{|c|c|c|c|c|c|}
\hline & \multicolumn{5}{|c|}{$\begin{array}{c}\text { Weight percentage of Oxides in different laterite } \\
\text { region }\end{array}$} \\
\hline Oxide & $\begin{array}{l}\text { Yaundé- } \\
\text { Nkolbisson } \\
\text { Cameroon }\end{array}$ & $\begin{array}{l}\text { South- } \\
\text { east of } \\
\text { Togo }\end{array}$ & $\begin{array}{l}\text { Awaé - } \\
\text { Yaoundé } \\
\text { Cameroon }\end{array}$ & $\begin{array}{l}\text { Yaoundé } \\
\text { Cameroon }\end{array}$ & $\begin{array}{c}\text { São Luis } \\
\text { Maranhao }\end{array}$ \\
\hline $\mathrm{SiO}_{2}$ & 45.9 & 43.83 & 56.2 & 46.18 & 80.56 \\
\hline $\mathrm{Al}_{2} \mathrm{O}_{3}$ & 28.7 & 24.83 & 11.1 & 27.2 & 11.93 \\
\hline $\mathrm{Fe}_{2} \mathrm{O}_{3}$ & 11.3 & 20.36 & 13.2 & 23.41 & 6.43 \\
\hline $\mathrm{SO}_{3}$ & 1.6 & - & - & & \\
\hline $\mathrm{TiO}_{2}$ & 1.5 & 0.8 & 1.1 & 1.84 & 0.91 \\
\hline $\mathrm{K}_{2} \mathrm{O}$ & 0.3 & 0.19 & 2.4 & 0.2 & \\
\hline $\mathrm{MnO}$ & 0.3 & 0.02 & - & & \\
\hline $\mathrm{P}_{2} \mathrm{O}_{5}$ & 0.2 & 0.08 & Traces & & \\
\hline $\mathrm{MgO}$ & 0.2 & 0.62 & 2.7 & 0.02 & 0.18 \\
\hline $\mathrm{CaO}$ & 0.02 & 0,14 & 2.1 & 1.04 & \\
\hline L.O. I & 12.0 & 9.1 & 9.5 & & \\
\hline
\end{tabular}


As an exploratory work the chemical composition of laterite samples from São Luis quarry, Brazil, was analysed. Table 1, also shows the São Luis lateritic soil composition. Comparing the chemical composition of the laterite of São Luis with the others presented in Table 1 , it can be observed that this one has the highest content of $\mathrm{SiO}_{2}$ and the lowest $\mathrm{Fe}_{2} \mathrm{O}_{3}$.

\subsection{Lateritic precursor activation}

The lateritic clay showed the presence of many platelets randomly stacked together with the presence of nanometer-sized iron nodules onto the surface of clay platelets as expected from literature [32, 33]. These nodules could correspond to ferrihydrite phases, which had been identified on natural clays and which were sitting on the surface of the platelets.

According Lecomte-Nana et al [29] the lateritic concretions-like geomaterial has been developed in acidic conditions $(\mathrm{pH}<4)$, where iron compounds are dissolved and after the complete dissolution of iron compounds, the addition of a basic solution in excess leads to the formation of a nanometric polymer (an iron hydrate gel). Thus, different of others precursor as flay ash, metakaolin, blast furnace slag, only activated by alkaline solutions, two reaction steps are normally applied to activated the lateritic soil: firstly the iron dissolution step in acidic conditions and secondly a neutralization and precipitation step in basic conditions. In fact, the few published works on the activation of lateritic soils have been used humic substances to promote the fixation of different cations, namely iron, aluminum, or silicon. Three acids have been used, namely: nitric acid $\left(\mathrm{HNO}_{3}\right)$, acetic acid $\left(\mathrm{CH}_{3} \mathrm{COOH}\right)$ and fulvic acid (organic acid). Fulvic acid is a low cost organic acid, which is biocompatible and can be easily available in tropical countries [34]. Fig. 3 illustrates the lateritic clay bridging during de acid base treatment.

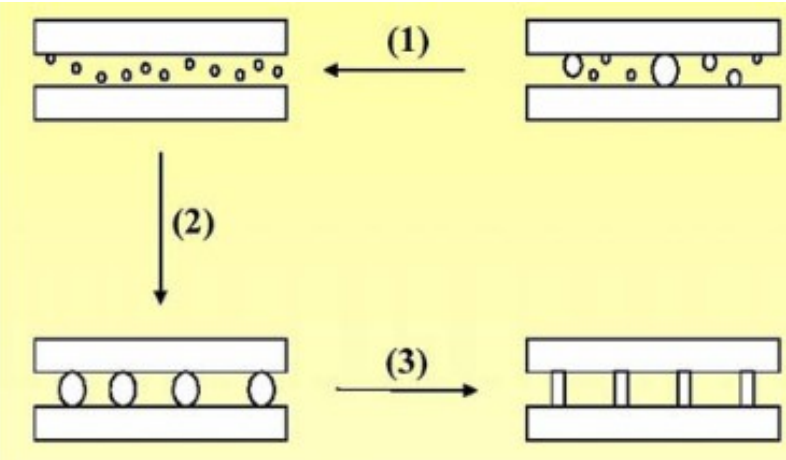

Fig.3 Lateritic clay bridging by iron polymer during the acidbase treatment [29]

The study realized with lateritic soil from Awaé, Yaoundé in Cameroon [29], found good results of compressive strength about $20 \mathrm{MPa}$ with a water/laterite weight ratio of 0.36 . This result was obtained dissolving the iron component of lateritic clay with the nitric acid and after alkaline activated by calcium hydroxide. Meanwhile samples issued from a reaction including fulvic acid exhibited good water resistance.
A study developed with the lateritic soil from Yaoundé-Nkolbisson in Cameroon was performed directly with the $\mathrm{NaOH}$ solution activation [10]. Compressive strength in the range of $12-51 \mathrm{MPa}$ was obtained. The compressive strength increased with the curing temperature and the amount of added $\mathrm{NaOH}$ in the system up to an optimum at $450^{\circ} \mathrm{C}$ (during $3 \mathrm{~h}$ ) and a $\mathrm{NaOH}$ solution of $8.5 \mathrm{M}$.

Laterite from Togo was activated using both phosphoric acid and alkaline sodium silicate solution and attained flexure strength and Young's modulus in the ranges $3.3-4.5 \mathrm{MPa}$ and $12-33 \mathrm{GPa}$, respectively [35].

Taking into account the chemical composition of the laterite of São Luis, presented in Table 1, one can firstly think that due to its low iron content, it will not be necessary to use acidic means for its dissolution. Although its alumina content is one of the smallest, such as that of the laterite of Awaé, it can be speculated that results similar to that found with the laterite of Awaé can also be obtained with the laterite of São Luis.

These aspects are sufficient signs for a study of alkaline activation of the laterite of São Luis to be the logical sequence of the observations reported here.

\section{Conclusions}

Considering the context of occurrence of lateritic soil in the state of Maranhão, it is observed that only on the island of São Luis the area of exploratory lateritic soil is sufficient for its use as a raw material of alkaline activated cements. By analogy with the still scarce studies carried out with laterites from Africa it is foreseeable that the lateritic soil of São Luis can be used as precursor of alkaline activated compounds. However, because of the diversity of the laterite chemical composition, especially in relation to the iron amount, further studies about acidic and alkaline activations are necessary.

\section{References}

1. I. Kheoruenromne, Red and yellow soils and laterite formation in the northeast plateau. Thailand Chem Geol (1987); 60:319-26.

2. R. Maignien, Compte rendu de recherches sur les latérites. UNESCO (1966):155.

3. S. Malomo, Mineralogy and chemistry of different fractions of some soil laterites from northeast Brazil. Chem Geol (1987); 60:101-9.

4. M.D. Gidigasu, Laterite soil engineering, Development in Geotechnical Engineering, vol. 9, Elsevier Scientific Publishing Company, Amsterdam, Netherlands (1976).

5. A.K. Kasthurba, M. Santhanam, M.S. Mathews, Investigation of laterite stones for building purpose from Malabar region, Kerala state SW India - Part 1: field studies and profile characterisation. Constr Build Mater (2007); 21:73-82. 
6. A.K. Kasthurba, M. Santhanam, M.S. Mathews, Investigation of laterite stones for building purpose from Malabar region Kerala state, south west India Part 3 chemical analysis and microstructure studies. Constr Build Mater; (2006) doi:10.1016/Construction and Building Materials, 22.003 .

7. P.N. Lemougna, U.F. Chinje Melo, E. Kamseu, A.B. Tchamba, Laterite based stabilized products for sustainable building applications in tropical countries: review and prospects for the case of Cameroon, Sustainability 3 (2011) 293-305.

8. G.L. Lecompte-Nana, E. Lesueur, J.P. Bonnet, G. Lecomte, Characterization of a lateritic geomaterial and its elaboration through a chemical route, Constr. Build. Mater. 23 (2009) 1126-1132.

9. F. Davidovits, J. Davidovits, M. Davidovits, R. Davidovits, Geopolymer cement of the calcium ferro-aluminosilicate polymer type and production process, Patent WO/2012/056125, 2012.

10. P.N. Lemogna, A.B. Madi, E. Kamseu, U.C. Melo, M.-P. Delplancke, H. Rahier, Influence of the processing temperature on the compressive strength of $\mathrm{Na}$ activated lateritic soil for building applications, Constr. Build. Mater. 65 (2014) 60-66.

11. P. Duxson, A. Fernández-Jimenéz, J.L. Provis, G.C. Lukey, A. Palomo, J.S.J. van Deventer, Geopolymer technology: the current state of the art, J. Mater. Sci. 42 (2007) 2917-2933.

12. D. Khale, R. Chandhary, Mechanism of geopolymerization and factors influencing its development: a review, J. Mater. Sci. 42 (2007) 729-746.

13. B.C. McLellan, R.P. Williams, J. Lay, A. van Riessen, G.D. Corder, Costs and carbon emissions for geopolymer pastes in comparison to ordinary Portland cement, J. Clean. Prod. 19 (2011) 10801090.

14. R. Maignien, Review of Research on Laterite. Natural Resource Research IV (1966); UNESCO Paris France.

15. P.K. Banerjee. Basic research on laterites in tropical countries. Quatern Int (1998); 51-52:69-72.

16. L. B. Bernucci, (1995) Considerações sobre o dimensionamento de pavimentos utilizando solos lateríticos para rodovias de baixo volume de tráfego. Tese de Doutorado. Escola Politécnica da USP Universidade de São Paulo.

17. R. Maignien, Compte rendu de recherches sur les latérites. UNESCO (1966) :155.

18. D.O.A. Osula, A comparative evaluation of cement ad lime modification of laterite. Eng Geol (1996); 42:71-81.

19. N. Billong, U.C. Melo, F. Louvet, D. Njopwouo, Properties of compressed lateritic soil stabilized with a burnt clay lime binder: effect of mixture components. Constr Build Mater (2009); 23:235760 .
20. L. Mbumbia, A.M. Wilmars, J. Tirlocq, Performance characteristics of lateritic soil bricks fired at low temperatures: a case study of Cameroon. Constr Build Mater (2000); 14:121-31.

21. M.D. Rahman, The potentials of some stabilizers for the use of lateritic soil in construction. Build Environ (1986); 21:57-61.

22. D.F. Villibor, J. Nogami, (2009). Pavimentos Econômicos - Tecnologia do uso dos Solos Finos Lateríticos. São Paulo: Editora Arte \& Ciência .

23. C. R. Espindola, N. R. Boni, Fragilidade dos mantos de alteração no Nordeste Ocidental Maranhense sob as condições atuais. IX Reunião Brasileira de Manejo e Conservação do Solo e da Água, Jaboticabal, (1992). Soc. Brasileira de Ciência do Solo, Programa e Resumos. p.103.

24. M.B. Diop, M.W. Grutzeck, Low temperature process to create brick. Constr Build Mater (2008); 22:1114-21.

25. R. Yousef, B. El-Eswed, M. Alshaaer, F. Khalili, H. Rahier, Degree of reactivity of two kaolinitic minerals in alkali solution using zeolitic tuff or silica sand filler. Ceram Int (2012); 38:5061-7.

26. G.F. Ngon Ngon, R. Yongue-Fouateu, D.L. Bitom, P. Bilong, A geological study of clayey laterite and clayey hydromorphic material of the region of Yaoundé (Cameroon): a prerequisite for local material promotion. J Afr Earth Sci (2009); 55:6978.

27. A.B. Madi, E. Kamseu, U.C. Melo, M.P. Delplancke, H. Rahier, Influence of the processing temperature on the compressive strength of $\mathrm{Na}$ activated lateritic soil for building applications. Construction and Building Materials 65 (2014) 60 66

28. H. Goure-Doubi, G. Lecomte-Nana, F. Nait-Abbou, B. Nait-Ali, A. Smith, V, Coudert, L. Konan, Understanding the strengthening of a lateritic "geomimetic" material. Construction and Building Materials 55 (2014) 333-340

29. G.L. Lecomte-Nana, E. Lesueur, J.P. Bonnet, G. Lecomte, Characterization of a lateritic geomaterial and its elaboration through a chemical route. Construction and Building Materials 23 (2009) 1126-1132

30. C. Boutterin, J. Davidovits, Réticulation Géopolymérique (LTGS) et Matériaux de Construction. Géopolymère (2003); 1:79-88.

31. M.B. Diop, M.W. Grutzeck, L. Molez, Comparing the performances of bricks made with natural clay and clay activated by calcination and addition of sodium silicate. Appl Clay Sci (2011); 54:172-8.

32. H.H. Patterson, C.S. Cronan, S. Lakshman, B.J. Plankey, T.A. Taylor. Comparison of soil fulvic acids using synchronous scan fluorescence spectroscopy, FTIR, titration and metal complexation kinetics. Sci Total Environ (1992); 113 (1-2):179-96. 
33. D.I. Kreller, M.A. Schlautman, S.L. McGunigale. Combined HPLC/HPSEC study of Suwannee River Fulvic Acid adsorptive fractionation on a-aluminum oxide. J Colloid Interface Sci (2013); 390(1):242-9.

34. B. Eyheraguibel Caractérisation des subtances humiques biomimétiques - effets sur les végétaux. Thesis, Toulouse Polytechnic National Institute (Elite Engineering University), 2004.

35. M. L. Gualtieri, M. Romagnoli, S. Pollastri, A. F. Gualtieri. Inorganic polymers from laterite using activation with phosphoric acid and alkaline sodium silicate solution: Mechanical and microstructural properties. Cement and Concrete Research 67 (2015) 259-270. 